\title{
Taxonomical features of stigmas of tribe Lithospermeae DC. (Boraginaceae) species in Asiatic Russia
}

\author{
Olga Nikiforova ${ }^{1 *}$ \\ ${ }^{1}$ Central Lab of Systematics of Higher Vascular Plants, Central Siberian Botanical Garden, \\ Novosibirsk, Russian Federation
}

\begin{abstract}
With the help of scanning electron microscopy, morphology of stigmas and shapes of papillae were studied for 11 species (from Asiatic Russia) of genera Lithospermum L., Buglossoides Moench, Cerinthe L., Echium L., and Onosma L., belonging to tribe Lithospermeae, and two species of the genus Botriospermum Bunge of unknown taxonomical affiliation in the family Boraginaceae. It was revealed that the shapes of the stigma and papillae can be useful for clarifying relationships among the species and genera, thus complementing the data for compiling a fuller and more correct taxonomy of the family Boraginaceae.
\end{abstract}

\section{Introduction}

The first systematic data on stigma morphology of flowering plants appeared in the works of Y. Heslop-Harrison, K. R. Shivanna [1] and Y. Heslop-Harrison [2], where they determined that stigmas of family Boraginaceae species are of the type "dry, papillate, where papillae are unicellular," abbreviated as DPU. This means that stigmas are of the dry type without cells on the surface excreting a liquid, and that papillae have unicellular structure.

Taxonomical value of stigma features was first indicated by German botanists J. Grau and A. Schwab [3] during classification of the genus Myosotis L. s. 1. (tribe Myosotideae Reichenb., Boraginaceae). Subsequently, the idea of studying stigmas of Boraginaceae species has been supported by M. Bigazzi and F. Selvi [4]. They have described morphological diversity of stigmas and papillae in 62 species of 15 genera of tribe Boragineae, developed terminology for describing features of papillae, and showed that every papilla consists of two parts: a neck that is connected to the surface of the stigma and an inflated cup of various shapes.

More detailed history of stigma research for Boraginaceae species is described in a study by the present author [5].

To date, only for two genera of tribe Lithospermeae DC. (Boraginaceae)-SouthAfrican Lobostemon Lehm. and ancient Mediterranean Onosma L. [6, 7]—stigmas and papillae have been studied.

\footnotetext{
* Corresponding author: nikiforovansk@yandex.ru
} 
Because at present, systematic information on stigma morphology of Eurasian species of tribe Lithospermeae is absent, we decided to study them, by means of a scanning electron microscope.

\section{Materials and methods}

Materials for the study were herbarial collections of the Central Siberian Botanical Garden SB RAS (NSK, NS). Stigma morphology and papillae shape were investigated under a Carl Zeiss EVO MA 10 scanning electron microscope. The methods of this study have been described by the present author elsewhere [5]. For the description of stigmas and papilla shape, the terminology proposed by Bigazzi and Selvi [4] was used.

\section{Results and discussion}

\subsection{Tribe Lithospermeae DC.}

This tribe includes $\sim 25$ genera and 460 species, which mainly grow in the Mediterranean and Iran-Turan provinces of the Ancient Mediterranean. The modern taxonomy of tribe Lithospermeae [8], based on molecular-genetic research into Boraginaceae species, is much different from M.G. Popov's taxonomy outlined in the "Flora of USSR" [9]. The tribe is now considered in a broader scope and includes genera previously placed in independent tribes Alkaniaea DC., Cerintheae DC., Echieae DC., and Moltkiopsidinae Riedl. This classification, in our opinion, more precisely matches the placement of genera in the family Boraginaceae and is consistent with the notion of greater significance of fruit features (gynobases and erems) compared to the features of the flower.

Eleven species of six genera grow in Asiatic Russia. The genus Onosma L. includes four species, Lithospermum L. includes two, and the other genera (Buglossoides Moench, Echium L., Cerinthe L., and Botriospermum Bunge) are single-species taxa.

\subsubsection{Genus 1: Lithospermum L.}

This genus includes $\sim 50$ species, mainly growing in North and South America and the Mediterranean. On the Asiatic-Russia territory, two species occur: $L$. officinale $L$. and $L$. erythrorhizon Siebold et Zucc.

Below are the results of our study on these species' stigmas.

L. officinale has a stigma that is pronouncedly low-pyramidal, 170-180 $\mu \mathrm{m}$ long, and up to $87 \mu \mathrm{m}$ wide; in the middle, it is slightly divided into two lobes. Papillae are well spaced on the stigma surface and are long, vermiform, 5-9 $\mu \mathrm{m}$ long, and 2.0-3.5 $\mu \mathrm{m}$ wide; on the convex cap of a papilla, round tubercles are clearly visible. Vermiform papillae are revealed for the first time; therefore, here we provide a description of this shape: papillae are long and vermiform; their length is twice (or more) greater than width, and a neck is absent; they are connected to the stigma surface via the base along the entire length.

L. erythrorhizon has a stigma that is flatter, 168-170 $\mu \mathrm{m}$ long, and up to $40 \mu \mathrm{m}$ high; the lobes are rounded and more pronounced. Papillae are moderately densely located on the stigma surface and are represented by two shapes. Most papillae are lageniform: the neck is short, and the cap is rounded, 4.0-4.8 $\mu \mathrm{m}$ long, and 3.5-4.7 $\mu \mathrm{m}$ wide; the surface is convex, with clearly visible round tubercles. Between lageniform papillae, a few vermiform papillae are located, 5.0-6.0 $\mu \mathrm{m}$ long and 1.2-2.0 $\mu \mathrm{m}$ wide. 


\subsubsection{Genus 2: Buglossoides Moench}

This genus includes 10-15 species, among which, B. arvensis (L.) I.M. Johnst is widespread. In the "Flora of USSR," it was assigned to the genus Lithospermum, from whose species it is distinguished by erems with a tuberous surface without spines; these erems are not smooth and shiny.

B. arvensis has a bilobate stigma, which is $227 \mu \mathrm{m}$ long and $116 \mu \mathrm{m}$ high; the lobes are rounded-spherical. Papillae are moderately densely located on the stigma surface and are represented by two shapes. Most papillae are lageniform, 9.0-10.0 $\mu \mathrm{m}$ long, and $\sim 5.0 \mu \mathrm{m}$ wide. The neck is short, via which a papilla is connected to the stigma surface. Furthermore, a few vermiform papillae can be seen. The presence of the vermiform papillae on the stigma surface in $B$. arvensis indicates a relationship between this species and the genus Lithospermum.

\subsubsection{Genus 3: Cerinthe L.}

In the "Flora of USSR," this genus was included in monotypic tribe Cerintheae. On the Asiatic-Russia territory, only one species grows: C. minor L., which sporadically occurs in Altai and West Siberia.

To characterize morphological diversity of the features of stigmas and papillae, stigmas of the widespread species C. minor from two regions - Altai Krai and the Caucasus-were studied. It was found that stigma shapes and papilla shapes are similar between the plants from the different regions, but papilla surfaces differ. The Caucasian plants have almost smooth papilla surfaces, whereas the Altai plants have tuberculate papilla surfaces.

C. minor has a flat stigma with a small depression in the middle, which divides it into faint lobes; the stigma is $137-305 \mu \mathrm{m}$ long and $48-85 \mu \mathrm{m}$ high, similarly to the stigma of the genus Lithospermum, but in terms of papilla shapes, it is close to species of the genus Onosma. Papillae are densely located on the stigma surface, are lageniform, big, 12-14 $\mu \mathrm{m}$ long, and 9-10 $\mu \mathrm{m}$ wide; the neck is very short and thick, and the cap is lobate and convex, with different numbers of lobes; thus, the shapes and sizes of papillae are also different.

\subsubsection{Genus 4: Echium L.}

This ancient Mediterranean genus includes more than 40 species. On the Asiatic-Russia territory, only one annual-biennial species grows-Echium vulgare L.- which occurs in dry open spaces, forest steppes, fallows, and weedy locations. In the "Flora of USSR," this genus was included in tribe Echieae because its species have a zygomorphic corolla and a bifid column. Nonetheless, in terms of gynobase shape and erem morphology, it is close to tribe Lithospermeae.

The stigma is undivided, hemispherical, $80-81 \mu \mathrm{m}$ long, and 58-60 $\mu \mathrm{m}$ wide. Papillae are vermiform, 15-20(25) $\mu \mathrm{m}$ long and 5.0-6.5 $\mu \mathrm{m}$ wide, located mainly along the stigma. The cap of the papillae is swollen and tuberous, and tubercles have different sizes and are spherically swollen. The vermiform shape of the papillae of Echium vulgare shows its relationship with the species of tribe Lithospermeae, especially L. officinale.

\subsubsection{Genus 5: Onosma L.}

This genus includes 150 species, and the greatest diversity is noted for the Ancient Mediterranean territory.

We studied stigmas of four species (Fig.): O. simplicissimum L., O. gmelinii Ledeb., $O$. transrhymnense Klok. ex Popov, and O. setosa Ledeb. The first three species grow in 
Siberia; in the East, their areal is limited by the Yenisei River; to the east of it, Onosma species are absent. $O$. setosa is a West-European species closely related to $O$. transrhymnense.
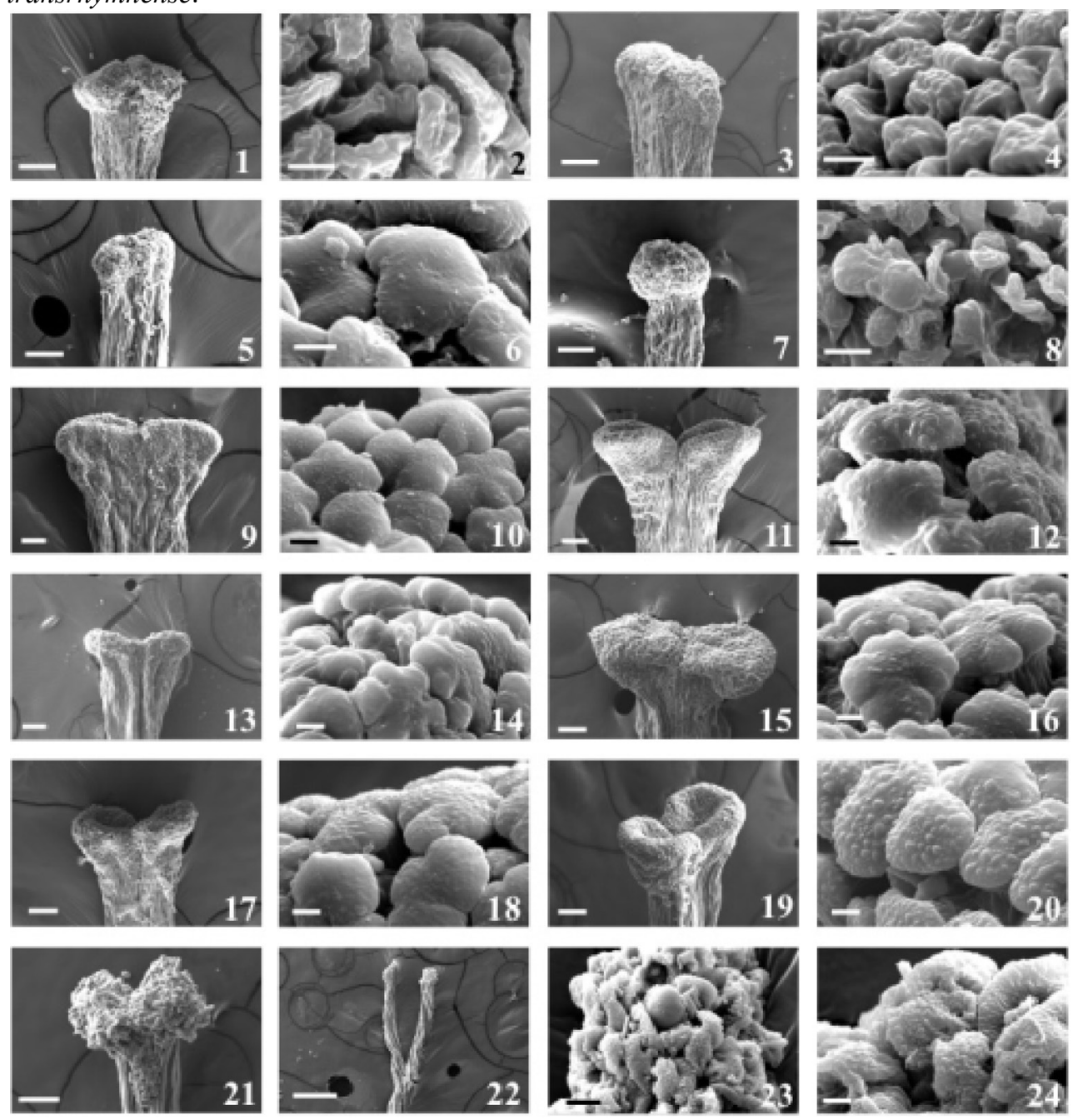

Fig. Shapes of stigmas and papillae in species of tribe Lithospermeae DC. from Asiatic Russia. Panels 1, 3, 5, 7, 9, 11, 13, 15, 17, 19, 21, and 22: the shape of the stigma; 2, 4, 6, 8, 10, 12, 14, 16, 18, 20, 23, and 24: the shape of papillae; 1 and 2: Lithospermum officinale; 3 and 4: L. erythrorhizon; 5 and 6: Cerinthe minor; 7 and 8: Botriospermum tenellum; 9 and 10: Onosma simplicissimum; 11 and 12: O. gmelinii (Khakassia); 13 and 14: O. gmelinii (Altai Republic); 15 and 16: $O$. transrhymnense (Novosibirsk Oblast); 17 and 18: O. setosa; 19 and 20: O. transrhymnense (Krasnoyarsk Krai); 21: Buglossoides arvensis; and 22-24: Echium vulgare. Scale bars: $60 \mu \mathrm{m}(1,3$, $5,7,9,11,13,15,17,19,21$, and 22) and $4 \mu \mathrm{m}(2,4,6,8,10,12,14,16,18,20,23$, and 24).

O. simplicissimum has a slightly bilobate stigma, which is sinuate throughout almost the entire, length, 250-400 $\mu \mathrm{m}$ long, and 90-108 $\mu \mathrm{m}$ high. Papillae are moderately densely located on the stigma surface, are lageniform, 11-13 $\mu \mathrm{m}$ long, and 9-11 $\mu \mathrm{m}$ wide; the neck is short, the cap is rounded and slightly lobed, and the lobes have different sizes; their surface is almost smooth, with subtle small tubercles.

For comparative morphological analysis, we investigated the stigmas of $O$. simplicissimum from different geographical areas: Altai Krai and the Republic of 
Khakassia. It was revealed that stigma and papilla shapes are stable throughout the areal, but the Khakassian plants have more prolonged papillae and big lobes.

$O$. gmelinii has a pronouncedly bilobate stigma, which is sinuate almost throughout the entire length, is $260-408 \mu \mathrm{m}$ long and $71-100 \mu \mathrm{m}$ high. Papillae are dense on the stigma surface, are lageniform, 12-20 $\mu \mathrm{m}$ long, and (11)14-20 $\mu \mathrm{m}$ wide; the neck is more or less long; the cap is rounded and big-lobed, with lobes of different sizes.

Stigmas of O. gmelinii from two locations-the Altai Republic (Kosh-Agach) and the Republic of Khakassia - were studied too. It was revealed that stigma and papilla shapes are stable, i.e., do vary among geographic locations, but the papillae surface varies: specimens from Kosh-Agach have a slightly tuberous surface, whereas Khakassian specimens have a coarse tuberous surface.

O. transrhymnense has a flat bilobate stigma, which is deeply sinuate almost throughout the entire length, is 420-469 $\mu \mathrm{m}$ long and 105-106 $\mu \mathrm{m}$ high. Papillae are dense on the stigma surface, lageniform, 14-20 $\mu \mathrm{m}$ long, and 9-18 $\mu \mathrm{m}$ wide; the neck is more or less long; the cap is rounded and big-lobed, sometimes with almost solid edges; the surface is coarse and tuberous.

$O$. transrhymnense is a polymorphous species and was studied on specimens from two locations, Novosibirsk Oblast and Krasnoyarsk Krai. The specimens from Novosibirsk Oblast have papillae that are more or less spaced on the stigma surface, the neck is longer, and the surface is almost smooth, with subtle tubercles. The specimens from Krasnoyarsk Krai have a shorter neck of the papilla and a coarse tuberous surface.

$O$. setosa (from the Republic of Kalmykia) has a bilobate stigma, which is deeply sinuate almost throughout the entire length, is 308-320 $\mu \mathrm{m}$ long and $80-85 \mu \mathrm{m}$ high. Papillae are densely located on the stigma surface, are lageniform, 14-20 $\mu \mathrm{m}$ long, and 9$18 \mu \mathrm{m}$ wide; the neck is more or less long; the cap is rounded and big-lobed, and the surface is coarse and tuberous.

Comparative morphological analysis suggested that stigma and papilla shapes of $O$. setosa are similar to those of a closely related species, O. transrhymnense.

\subsubsection{Genus 6: Botriospermum Bunge}

This East-Asian genus includes approximately four annual species; on our territory, only one species-B. tenellum (Hornem.) Fisch. et C.A. Mey-grows. The placement of this genus in the family Boraginaceae is still ambiguous. In the "Flora of USSR," it was assigned to independent tribe Botriospermeae, but the flat type of gynobases brings it together with the genera of tribe Lithospermeae; therefore, additional research, in particular, on stigma features, should help to reveal its relationships.

B. tenellum has an undivided stigma that is almost spherical, 130-135 $\mu \mathrm{m}$ long, and 95$100 \mu \mathrm{m}$ high. Papillae are spaced on the stigma surface, are vermiform, 5.0-8.5 $\mu \mathrm{m}$ long, and 1.0-2.5 $\mu \mathrm{m}$ wide; the neck is high, the cap is fusiform-tortuous, and the surface is smooth.

B. secundum has an undivided stigma that is almost spherical, $136 \mu \mathrm{m}$ long, and 93-95 $\mu \mathrm{m}$ high. Papillae are spaced on the stigma surface, are vermiform, 7-9 $\mu \mathrm{m}$ long, and 2.2$4.0 \mu \mathrm{m}$ wide; the neck is high, the cap is fusiform-tortuous, and the surface is smooth.

Therefore, for the species of tribe Lithospermeae, three types of stigma are characteristic: undivided or slightly bilobate, bilobate, or bifid. For genera Onosma and Cerinthe, lageniform papillae are characteristic. Lithospermum officinale, Echium vulgare, Botriospermum tenellum, and B. secundum have vermiform papillae. On the stigmas of Lithospermum erythrorhizon and Buglossoides arvensis, papillae of two types occur: lageniform and vermiform. The lageniform papilla shape of species of tribe Lithospermeae is different from that of species of tribes Myosotideae and Boragineae: the latter have a 
short neck and a rounded-lobate cap. In terms of stigma and papilla shapes, the genus Onosma is an outlier in tribe Lithospermeae: its species have a bilobate, deeply sinuate stigma and lageniform papillae, which are big-lobed and morphologically similar to the papillae of ancient Mediterranean species Onosma pachypoda Boiss. and O. gaubae Bornm. This finding gives us a reason to suppose Ancient Mediterranean genesis of the Asiatic-Russia species. Thus, in the family Boraginaceae, a new vermiform shape of papillae was revealed.

\section{References}

1. Heslop-Harrison Y., Shivanna K.R.. Ann. Bot. 41 (London, 1977)

2. Heslop-Harrison Y. Nord. J. Bot. 1 (1981)

3. Grau J., Schwab A.. Mitt. Bot. Staatssam. 18 (Munchen, 1982)

4. Bigazzi M., Selvi F. Canadian Journal of Botany, 78) (2000)

5. O.D. Nikiforova. Turczaninowia, 23 (2020)

6. M. H. Buys. South African Journal of Botany, 67 (2001)

7. A-R.Mehrabian, M. Arabameri, S. Sadeghi. Bangladesh J. Bot. 46 (2017)

8. J. Chacon, F. Luebert, H.H. Hilger, S. Ovchinnikova, F. Selvi, L. Cecchi, C.M. Gulliams, K. Hasenstab-Lehman, K. Sutory, M.G. Simpson, M. Weigend. Taxon, 65 (2016)

9. M.G. Popov. Family Boraginaceae. Flora of the USSR, 19 (1953) 


\section{Figure caption}

\section{O.D. Nikiforova "Taxonomical features of stigmas of tribe Lithospermeae DC. (Boraginaceae) species in Asiatic Russia"}

Figure. Shapes of stigmas and papillae in species of tribe Lithospermeae DC. from Asiatic Russia.

Panels $1,3,5,7,9,11,13,15,17,19,21$, and 22: the shape of the stigma; 2, 4, 6, 8, 10, 12 , 14, 16, 18, 20, 23, and 24: the shape of papillae; 1 and 2: Lithospermum officinale; 3 and 4: L. erythrorhizon; 5 and 6: Cerinthe minor; 7 and 8: Botriospermum tenellum; 9 and 10: Onosma simplicissimum; 11 and 12: O. gmelinii (Khakassia); 13 and 14: O. gmelinii (Altai Republic); 15 and 16: O. transrhymnense (Novosibirsk Oblast); 17 and 18: O. setosa; 19 and 20: O. transrhymnense (Krasnoyarsk Krai); 21: Buglossoides arvensis; and 22-24:

Echium vulgare.

Scale bars: $60 \mu \mathrm{m}(1,3,5,7,9,11,13,15,17,19,21$, and 22) and $4 \mu \mathrm{m}(2,4,6,8,10,12$, $14,16,18,20,23$, and 24). 